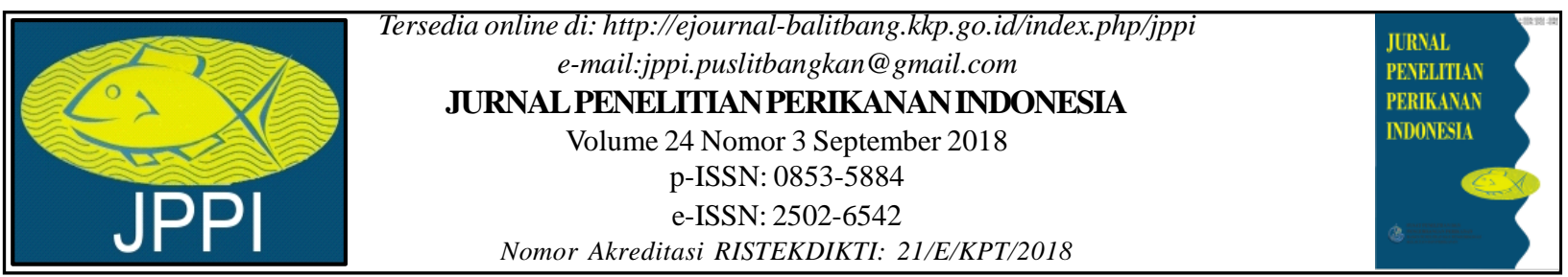

\title{
PEMODELAN DAERAH POTENSIAL KEMUNCULAN HIU PAUS (Rhincodon typus) MENGGUNAKAN DATA PENGINDERAAN JAUH DI PERAIRAN PROBOLINGGO, JAWA TIMUR
}

\section{MODELING OF POTENTIAL OCCURRENCE ZONES OF WHALE SHARK (Rhincodon typus) USING REMOTELY SENSED DATA IN PROBOLINGGO WATERS, EAST JAVA}

\author{
Achmad Fachruddin Syah¹, Musrifah', Hendrik Cahyono' \\ ${ }^{1}$ Program Studi Ilmu Kelautan, Fakultas Pertanian, Universitas Trunojoyo Madura, JI. Raya Telang, PO. \\ BOX 2 Kamal, Bangkalan, Madura, Jawa Timur-69162, Indonesia \\ Teregistrasi I tanggal: 30 Mei 2018; Diterima setelah perbaikan tanggal: 26 September 2018; \\ Disetujui terbit tanggal: 28 September 2018
}

\begin{abstract}
ABSTRAK
Perairan Probolinggo merupakan salah satu lokasi agregasi musiman hiu paus (Rhincodon typus) di Indonesia sejak beberapa tahun terakhir. Hiu paus di perairan Probolinggo banyak dijumpai pada bulan Desember sampai Maret, meskipun kemunculan dapat terjadi sepanjang tahun di sekitar pantai utara Pulau Jawa. Hiu paus telah dimasukkan sebagai salah satu spesies yang mendapatkan perlindungan penuh oleh dunia. Penelitian ini bertujuan untuk membangun model pendugaan daerah kemunculan hiu paus di perairan pantai Probolinggo. Data kemunculan hiu paus bulan Januari sampai Maret 2016 diperoleh dari lembaga hiu paus Indonesia. Parameter oseanografi yang digunakan yaitu sea surface temperature (SST), dan konsentrasi klorofil-a (chla) diperoleh dari data penginderaan jauh, sedangkan kedalaman perairan berasal dari GEBCO (The General Bathymetryc Chart of the Oceans). Maximum entropy model digunakan untuk memprediksi habitat yang sesuai terhadap distribusi hiu paus dengan didasarkan pada parameter yang berpengaruh terhadap kemunculan hiu paus di perairan Probolinggo. Nilai area under curve (AUC) sebesar 0,997 menunjukkan bahwa model dapat memprediksi kesesuaian habitat hiu paus dengan sangat baik. Dari ketiga parameter yang diuji, kedalaman $(71,0 \%)$ menunjukkan sebagai parameter yang paling berpengaruh terhadap kemunculan hiu paus di perairan Probolinggo, disusul oleh chl-a (15,7\%) dan SST (13,3\%). Hasil juga menunjukkan hiu paus banyak ditemukan pada kedalaman $9-14$ meter dan chl-a $0,5-0,7 \mathrm{mg} / \mathrm{m}^{3}$ serta SST $29-30^{\circ} \mathrm{C}$. Distribusi hiu paus yang diperoleh memberi peluang untuk mengidentifikasi spesifik area dengan tingkat akurasi kehadiran yang tinggi di sepanjang pantai Probolinggo; pengenalan spesifik area ini dapat dijadikan dugaan untuk membangun manajemen praktis yang efektif untuk meningkatkan perlindungan hiu paus.
\end{abstract}

Kata Kunci: Maximum entropy model; potential daerah kemunculan; parameter oseanografi; perairan Probolinggo; hiu paus

\begin{abstract}
Probolinggo water is one of suitable sites of the whale sharks (Rhincodon typus) seasonal aggregation in Indonesia during the last years. Whale sharks in Probolinggo waters are common appear in December to March, although they can be seen years-around in the North Coast of Java Island. Whale sharks have been included as one of the full protected species of the world. This study aims to develop a model prediction of the whale sharks occurrence in Probolinggo coastal waters. The occurrence data of whale sharks from January to March 2016 was obtained from the whale sharks institute of Indonesia. The oceanographic parameters were used sea surface temperature (SST), and chlorophyll-a concentration (chl-a), obtained from remotely sensed data, while water depth derived from GEBCO (The General Bathymetryc Chart of the Oceans). Maximum
\end{abstract}


entropy models are used to predict suitable habitats for the distribution of whale sharks based on the influential parameters on the appearance of whale sharks in Probolinggo waters. The value of the under-curve area (AUC) of 0.997 indicates that the model can predict the suitability of whale sharks habitat excellent. Of the three parameters tested, depth $(71,0 \%)$ showed as the most parameters influenced the occurrence of whale sharks in this waters, followed by chl-a $(15,7 \%)$ and SST (13,3\%). Furthermore, the results showed that whale sharks were mostly found at depths of 9 - 14 meters, chl-a of 0,5-0,7 mg/m $\mathrm{m}^{3}$ and SST of $29-30^{\circ} \mathrm{C}$. The distribution of whale sharks obtained provides an opportunity to identify the specific areas with high attendance accuracy along Probolinggo waters; the recognition of the specific area can be used as starting points to develop effective management practices to improvewhale sharks protection.

\section{Keywords: Maximum entropy model; potential zones of occurrence; oceanographical parameters; Probolinggo waters; whale sharks}

\section{PENDAHULUAN}

Hiu paus (Rhincodon typus, Smith 1828) merupakan jenis hiu filter feederyang keberadaannya menyebar dari daerah tropis sampai dengan subtropis. Hiu paus dikategorikan sebagai hiu epipelagis dan dapat ditemukan di perairan samudera dan perairan pantai, terutama di daerah yang hangat. Walaupun hiu paus memiliki daerah distribusi yang luas, ada tempat-tempat tertentu di dunia sebagai daerah yang disukai oleh hiu paus. Beberapa tempat yang sering menjadi tempat akan munculnya hius paus secara musiman yaitu Ningaloo Reef, Australia (Taylor, 1996), Belize (Heyman et al., 2001), Seychelles (Rowat \& Gore, 2007), Maldives (Anderson \& Ahmed, 1993), dan Mexico (Eckert \& Stewart, 2001; de la ParraVenegas et al., 2011; Ketchum et al., 2012) dan yang terakhir di perairan Qatar (Robinson et al., 2013).

Secara umum distribusi dan kelimpahan hiu paus dipengaruhi oleh proses oseanografi seperti penaikan massa air (upwelling), arus pantai (coastal currents), dan fronts, yang meningkatkan produktivitas lingkungan sekitarnya (Taylor, 1996; Colman, 1997; Norman, 2002; Eckert \& Stewart 2001;Duffy, 2002). Mereka juga berasosiasi dengan suhu air hangat dan parameter lingkungan lainnya yang dapat meningkatkan produktivitas di lingkungan laut, mendukung terciptanya konsentrasi makanan yang terlokalisasi. Hiu paus mengkonsumsi berbagai jenis makanan mulai dari plankton yang kecil, seperti copepods dan euphausiids (Clark \&Nelson, 1997; Hacohen-Domené et al., 2006; Taylor, 2007; Ketchum et al., 2012) dan telor-telor ikan (Heyman et al., 2001; de la Parra-Venegas et al., 2011; Robinson et al., 2013) sampai organisme nektonis yang besar seperti cumi-cumi dan ikan (Last \&Stevens 1994; Duffy, 2002).

Analisa hubungan antara suatu spesies dengan lingkungannya merupakan hal yang selalu penting dalam suatu ekologi. Spesies laut sering berasosiasi dengan habitat biologi dan fisik tertentu, sehingga membangun ketertarikan untuk memahami peranan kondisi lingkungan dalam mengarahkan pola distribusi dan kelimpahan (Elith et al., 2011). Strategi paling umum untuk menduga distribusi geografis aktual atau potensial dari suatu spesies adalah dengan memahami karakteristik lingkungan yang cocok bagi spesies tersebut dan kemudian mengindentifikasi dimana lingkungan yang cocok tersebut terdistribusi secara spasial (Pearson, 2007).

Model distribusi spesies merupakan model empiris yang menghubungkan observasi lapangan terhadap variabel prediktor lingkungan yang didasarkan pada permukaan respon yang diturunkan secara statistik atau teori (Guisan \& Thuiller, 2005). Teori model distribusi spesies menyatakan bahwa model dapat memprediksi distribusi spasial potensial dari berbagai spesies, dengan menghubungkan titik kemunculan yang diketahui dengan variabel prediktor (Franklin, 2009; Hijmans \& Elith, 2011). Teknik pemodelan habitat didasarkan pada asumsi bahwa, untuk setiap spesies, ada satu set variabel lingkungan yang ideal yang membuat munculnya suatu spesies lebih memungkinkan.

Data umumnya ada dalam bentuk frekuensi kemunculan presence-only, yang menghadirkan tantangan lain untuk memprediksi kejadian, rentang, dan niches of spesies di lepas pantai. Data kemunculan (presence-only) dan variabel biofisik dapat digunakan untuk memprediksi secara tepat 'nichebased model' dengan menggunakan banyak metode. Model presence-only menghasilkan permukaan kesesuaian spasial secara eksplisit yang mewakili kesesuaian habitat (Elith et al., 2006). Pada tahun terakhir ini, ahli ekologi laut telah mulai menggunakan perangkat lunak pemodelan yang disebut maxent yang berakar pada maximum entropy (Edren et al., 2010). Dalam studi terbaru, maximum entropy (maxent) telah diterapkan pada ekosistem terestrial (Peterson et al., 2007) dan laut (Edren et al., 2010; Syah et al., 2016). Oleh karena itu, merupakan hal yang menarik untuk memahami pengaruh faktor oseanografi dan terbentuknya daerah potensial munculnya hiu paus dengan memanfaatkan data oceanografi yang diturunkan dari data penginderaan jauh diintergasikan dengan model distribusi spesies seperti "maxent". 


\section{BAHAN DAN METODE Lokasi Penelitian}

Penelitian ini dilakukan di perairan Probolinggo, yang merupakan salah satu kabupaten di Provinsi Jawa Timur, yang secara geografis terletak pada posisi $7^{\circ} 35^{\prime}-7^{\circ} 50^{\prime} \mathrm{LS}$ dan $113^{\circ} 10^{\prime}-113^{\circ} 30^{\prime}$ BT (Gambar 1). Panjang garis pantai mencapai $72 \mathrm{~km}$ dengan 7 kecamatan di wilayah pesisir. Perairan Kabupaten Probolinggo dikategorikan sebagai tipe perairan semi tertutup dan juga memiliki daerah pesisir yang landai (Maharani etal., 2014). Daerah pesisir Probolinggo membentang dari Kecamatan Tongas di bagian barat hingga Kecamatan Kraksaan di bagian timur. Sebelah selatan merupakan areal persawahan yang subur, sedangkan sebelah utara merupakan kawasan pertambakan (Suyarso, 2016).

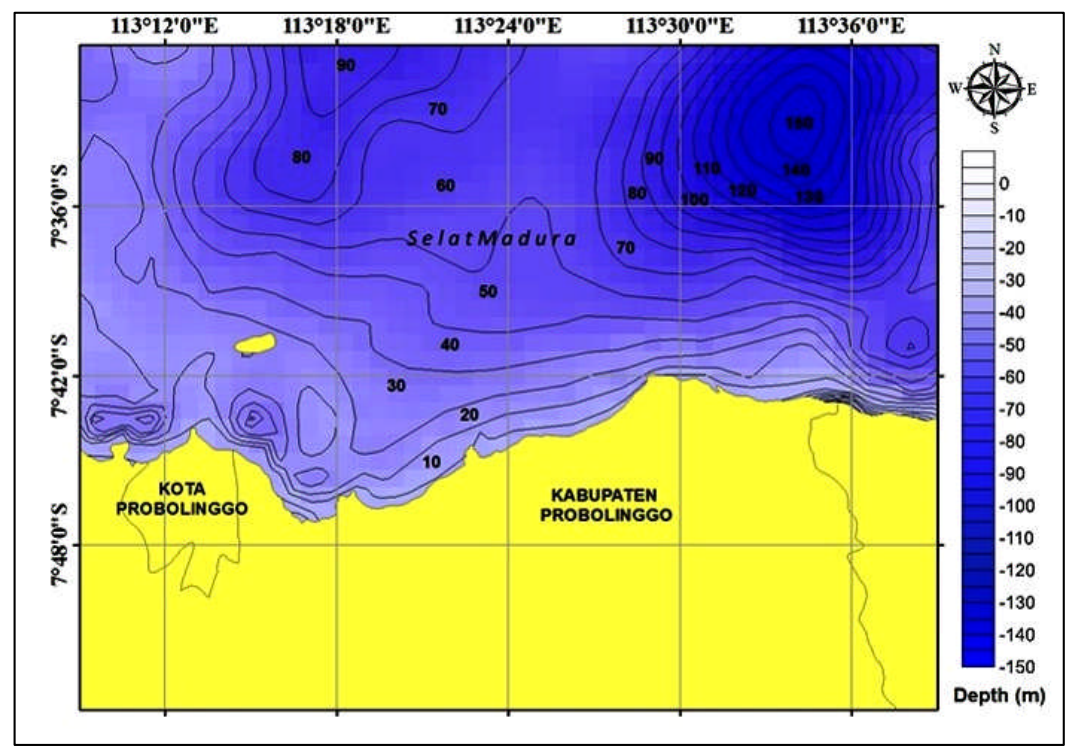

Gambar 1. Lokasi penelitian dan profil kedalaman perairan.

Figure 1. Study area and the depth profileof waters.

Pesisir Kabupaten Probolinggo merupakan muara dari beberapa sungai yang berhulu dari gunung api. Sepanjang pesisir Kabupaten Probolinggo hampir ditumbuhi oleh hutan mangrove, sehingga perairannya relatif subur. Suhu permukaan laut perairan pesisir Kabupaten Probolinggo berkisar $28^{\circ}$ sampai $31^{\circ} \mathrm{C}$ (Noviyanti, 2015). Arus permukaan perairan pesisir Kabupaten Probolinggo berkisar $0-0,17 \mathrm{~m} / \mathrm{s}$ (Sakuntala, 2016). Besaran arus permukaan tersebut menunjukkan bahwa rendahnya kecepatan arus pemukaan pesisir Kabupaten Probolinggo. Wilayah pesisir Probolinggo banyak menerima masukan berupa muatan antropogenik yang berasal dari limbah industri, limbah rumah tangga, dan Pembangkit Tenaga ListrikUap (PLTU).

\section{Data Posisi Kemunculan Hiu Paus dan Lingkungan}

Data posisi dan frekuensi munculnya hiu paus dalam penelitian ini diperoleh dari lembaga hiu paus Indonesia (http://whalesharkindonesia.org/). Data yang diperoleh merupakan data bulanan dari Januari - Maret 2016. Data sea surface temperature (SST) dan konsentrasi klorofil-a (chl-a) level 3 dengan resolusi spasial $4 \mathrm{~km}$ pada Januari - Maret 2016 yang diperoleh dari data penginderaan jauh digunakan pada model maximum entropy. Data bulanan SST dan chla diturunkan dari satellite images the Moderate Resolution Imaging Spectroradiometer (MODIS)-Aqua mission yang telah diunduh dari NASA Goddard Space Flight Center website diolah dengan menggunakan software SeaDAS. Data kedalaman (bathymetri) yang digunakan dalam penelitian ini berasal dari GEBCO (The General Bathymetryc Chart of the Oceans) diunduh dari website British Oceanographic Data Centre. (www.bodc.ac.uk). Data kedalaman GEBCO memiliki resolusi 30 Arc-Second atau kurang lebih 1 kilometer. Software Global Mapper, MS. Excel, dan ArcGis digunakan untuk mengolah data batimetri. Semua variabel lingkungan tersebut kemudian ditata ulang (resampled) ke resolusi $1 \mathrm{~km}$ sebelum mengkonstruksi model habitat.

\section{Analisis Data}

Software maximum entropy (versi 3.3.3k) yang tersedia di www.cs.princeton.edu/ schapire/maxent digunakan untuk membangun model. Environmental layers yang tergabung dalam basis model (model yang digunakan untuk prediksi spasial) resampled ke resolusi $1 \mathrm{~km}$ dan dikonversi ke format grid ESRII ASCII. Model dibangun dengan menggunakan default value untuk regulation parameters (1), maximum it- 
eration (5.000), dan automatic feature class selection. Cross-validation procedure digunakan untuk mengevaluasi kinerja model. Dalam membangun model, data dibagi secara acak menjadi 2 kategori, training data (75\%) dan test data (25\%). Training data digunakan untuk membangun model, sedangkan test data digunakan untuk menguji tingkat keakuratan model yang diperoleh. The area under the curve (AUC) metric of the receiver operating characteristic (ROC) curve digunakan untuk mengevaluasi kesesuaian model (Elith et al., 2006; Phillips et al., 2006).

\section{HASIL DAN BAHASAN \\ Hasil}

\section{Distribusi Spasial Dan Temporal}

Gambar 2 menunjukkan posisi kemunculan hiu paus selama periode Januari - Maret 2016. Pada Januari, hiu paus muncul di sisi sebelah barat perairan Probolinggo, sedangkan di sisi sebelah timur hiu paus muncul hanya pada Februari dan Maret. Hal ini mengindikasikan bahwa pada Januari-Maret hiu paus bergerak dari sisi barat ke sisi timur perairan Probolinggo.

\section{Model Perfomance}

Posisi kemunculan hiu paus dan faktor oseanografi digunakan untuk memprediksi daerah potensial kemunculan hiu paus di perairan Probolinggo menggunakan maximum entropy model. Hasil model maxent juga menunjukkan bahwa models' performance lebih baik daripada fitted by chance karena didukung oleh the modest values of the performance metric yang memperoleh nilai $>0.5$ $(A \cup C=0.985)$. Hasil ini menunjukkan keberhasilan prediksi yang tinggi dari model yang diperoleh (Phillips et al., 2006; Elith et al., 2006).

Relative percent contribution dari masing-masing variabel lingkungan ditunjukkan pada Tabel 1. Hasil menunjukkan faktor oseanografi yang paling berpengaruh terhadap distribusi kemunculan hiu paus adalah kedalaman dan chl-a dengan nilai percent contribution secara berturut-turut adalah $71,0 \%$ dan $15,7 \%$, sedangkan SST merupakan faktor yang mempunyai pengaruh paling kecil dengan nilai relative percent contribution sebesar $13,3 \%$.

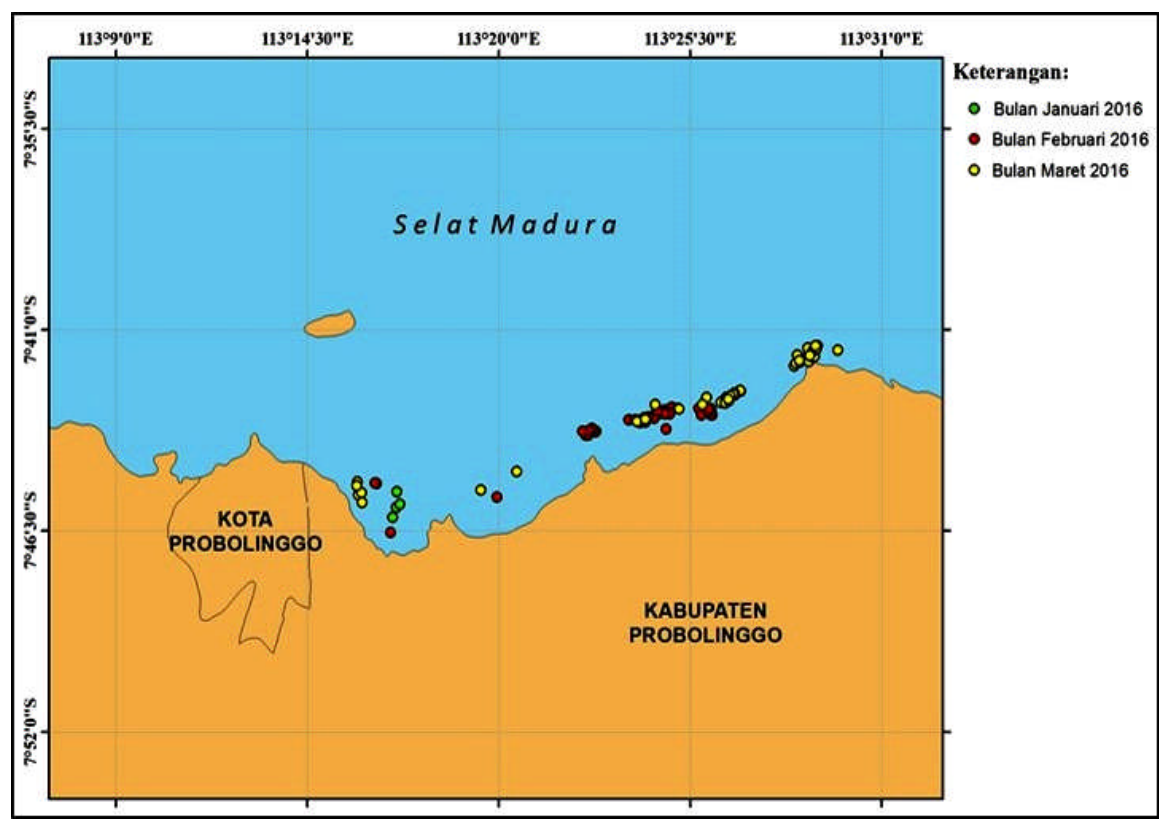

Gambar 2. Lokasi kemunculan hiu paus (Rhincodon typus) selama Januari - Maret 2016.

Figure 2. Occurrence location of whale shark (Rhincodon typus) during January - March 2016.

Tabel 1. Prosentase kontribusi relatif variabel lingkungan terhadap model yang diperoleh dari penggunaan maximum entropy.

Table 1. Relative percent contribution of environmental variables to models derived by using a maximum entropy approach

\begin{tabular}{cc}
\hline Variabel & Prosentase Kontribusi (\%) \\
\hline kedalaman & 71,0 \\
chl-a & 15,7 \\
SST & 13,3 \\
\hline
\end{tabular}


Gambar 3 menunjukkan the model-derived preferred ranges dari tiap parameter lingkungan. Kurva pada gambar tersebut menunjukkan perfomance dan kontribusi dari tiap parameter lingkungan terhadap perkiraan model (model fit). Probabilitas kemunculan yang tinggi (high probabilities of occurrence) hiu paus terobservasi pada range tertentu pada tiap parameter lingkungannya. Hiu paus mempunyai tingkat peluang kemunculan yang tinggi pada chl-a : $0,5-0,9 \mathrm{mg} /$ $\mathrm{m}^{3}$, SST: $29-30^{\circ} \mathrm{C}$ dan kedalaman perairan: $9-14 \mathrm{~m}$. (a)

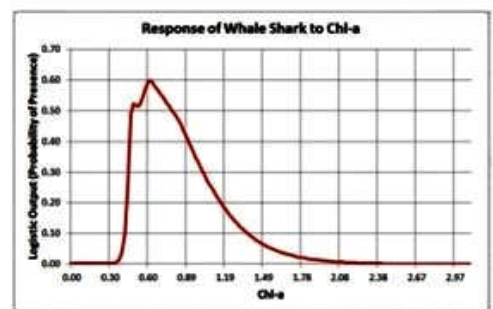

(b)

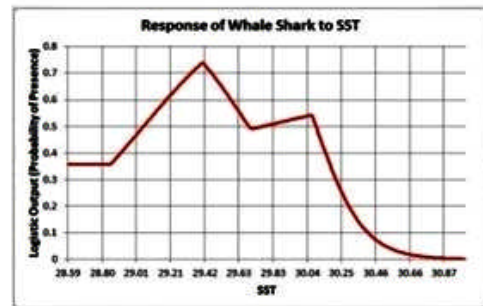

(c)

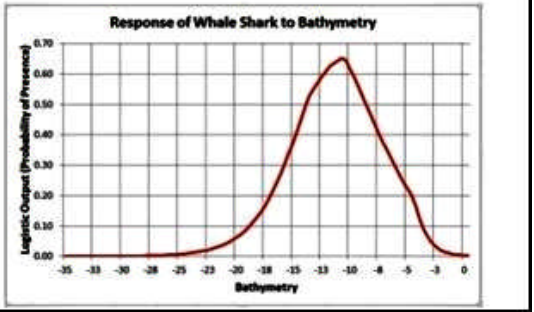

Gambar 3. Kurva respon dari model untuk (a) konsentrasi klorofil-a (chl-a), (b) sea surface temperature(SST), (c) kedalamanperairan.

Figure 3. Response curves from the model for (a) chlorophyll-a (chl-a), (b) sea surface temperature (SST), (c) water depth.

\section{Prediksi Kemunculan}

Peta predicted HSI (2017) ditampilkan pada Gambar 4. Pada Januari, the predicted probability of occurrence hiu paus belum terbentuk. The predicted probability of occurrence hiu paus terbentuk pada
Februari dan kemudian menghilang atau tinggal sedikit pada Maret. Ini mengindikasikan bahwa hiu paus hanya muncul pada periode tertentu saja. Pada penelitian ini frekuensi tertinggi munculnya hiu paus di perairan Probolinggo terjadi pada Februari.

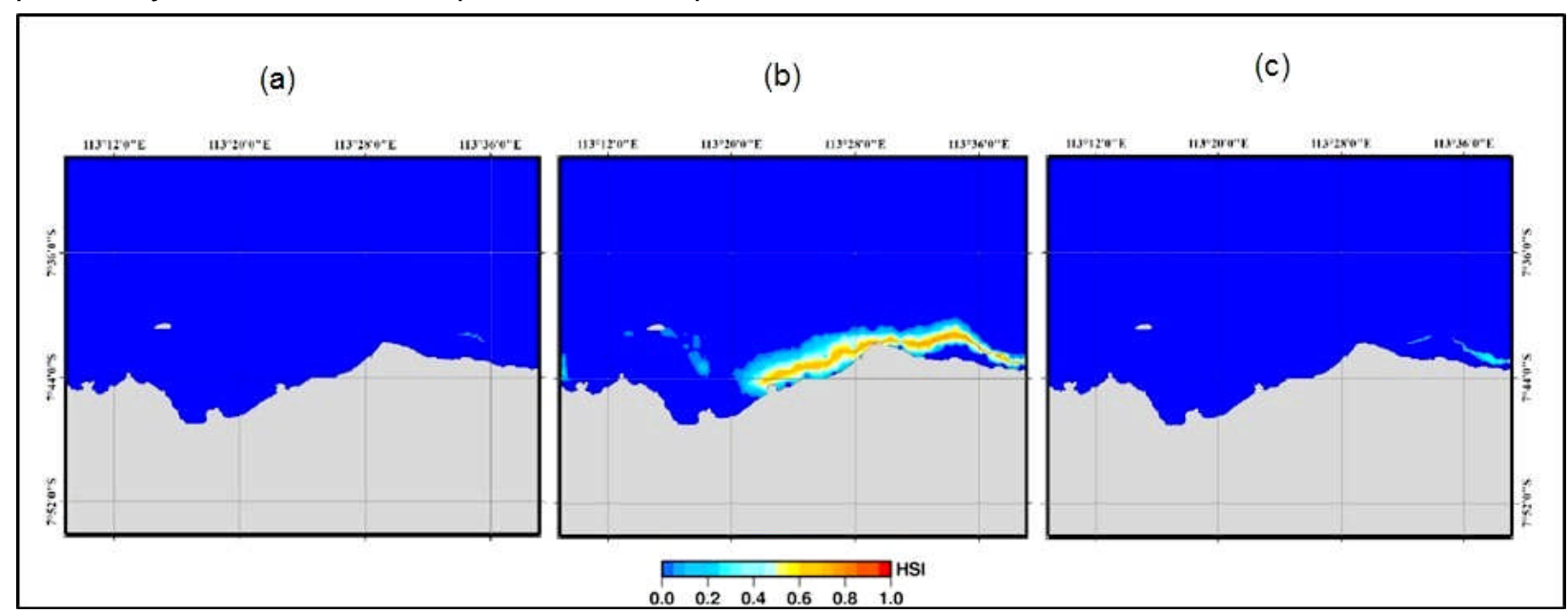

Gambar 4. Peta daerah potensial kemunculan hiu paus di Perairan Probolinggo pada tahun 2017 untuk bulan (a) Januari, (b) Februari, (c) Maret. The suitability digambarkan dengan Habitat Suitability Index (HSI) yang mempunyai range $0-1$, yang merepresentasikan "poor" to "good" habitat quality.

Figure 4. Potential occurrence zone maps of whale shark in Probolinggo waters in 2017 for (a) January, (b) Februari, (c) March. The suitability is depicted as an Habitat Suitability Index (HSI) score ranging from 0 to 1, representing "poor" to "good" habitat quality, respectively.

\section{Bahasan}

Hiu Paus (Rhincodon typus) merupakan spesies ikan berukuran terbesar di dunia. Spesies ini telah mencuri perhatian beberapa lembaga dunia pemerhati lingkungan seperti International Union for Conservation of Nature (IUCN) dan Convention on International Trade in Endangered Species of Wild Fauna and Flora
(CITES). Hiu paus mempunyai proses tumbuh berkembang dan mencapai dewasa yang lambat sehingga memiliki waktu pulih yang lama. Hal ini menyebabkan spesies ini termasuk dalam kategori spesies yang rentang dan rawan untuk mengalami kepunahan. Spesies ini mempunyai kemampuan migrasi jarak jauh hingga ribuan kilometer dan sering dijumpai di perairan subtropis bersuhu hangat dan 
perairan tropis seperti Indonesia (Stevens, 2007).

Pada penelitian ini digunakan posisi kemunculan hiu paus dan faktor oseanografi dari data penginderaan jauh dengan menggunakan maximun entropy model untuk memprediksi daerah potensial munculnya hiu paus di Perairan Probolinggo. Berdasarkan data kemunculan hiu paus, kita dapat memperkirakan sebaran berdasarkan lokasi dan waktu (the spatial and temporal distribution) daerah potensial kemunculan hiu paus. Pada Januari, tidak banyak hiu paus yang terlihat di perairan Probolinggo (Gambar 2). Pada bulan ini, hiu paus hanya nampak di sisi barat perairan Probolinggo. Hiu paus mulai banyak muncul pada Februari dan terlihat pada sisi barat dan timur perairan Probolinggo. Namun demikian, kemunculannya pada sisi timur lebih banyak dari sisi barat. Pada Maret, hiu paus juga muncul di sisi barat dan timur perairan Probolinggo. Bahkan sebagian muncul di sisi yang lebih timur dari kemunculanya pada Februari. Hal ini menunjukkan bahwa hiu paus bergerak dari sisi barat ke sisi timur perairan Probolinggo pada Januari sampai dengan Maret. Kemunculan hiu paus ke permukaan diduga terkait dengan aktivitas makan, yaitu menyaring air untuk mendapatkan zooplankton yang komposisinya didominasi oleh Lucifer dan Copepoda (Heyman et al., 2001; Noviyanti, 2015). Di Baja California, kemunculan hiu paus meningkat pada musim semi ketika kelimpahan Copepoda tinggi, dan di Ningaloo Reef, Australia bagian barat, mereka meluangkan waktunya selama terjadinya masa pemijahan karang dan terkait dengan meningkatnya kelimpahan krill (Taylor, 1996). Sedangkan, di Belize, hiu paus yang diamati memakan telor ikan kakap (Lutjanidae) yang berkumpul secara musiman untuk bertelur (Heyman et al., 2001).

Pada saat lahir, hiu paus dapat mencapai ukuran panjang antara $55-64 \mathrm{~cm}$. Pada saat belum matang gonad, hiu paus jantan bisa mencapai ukuran 2,99 $\mathrm{m}$, sedangkan pada saat remaja bisa mencapai ukuran antara 3,90 -5,40 $\mathrm{m}$ dan pada saat dewasa bisa mencapai ukuran sekitar 12,0 m (Compagno, 2002). Noviyanti (2015) melaporkan bahwa hiu paus yang muncul di perairan Probolinggo berkisar antara 2-8 meter, diduga belum mengalami pemijahan.

The performance of the maximum entropy model sangat tinggi, dimana nilai AUC > 0.9 mengindikasikan bahwa model dapat memprediksi daerah potential kemunculan hiu paus dengan sangat baik. Distribusi suatu biota laut sangat dipengaruhi oleh faktor lingkungan. Pada penelitian ini kedalaman perairan menunjukkan sebagai faktor lingkungan yang paling berpengaruh terhadap distribusi dan kemunculan hiu paus dimana hiu paus banyak ditemukan pada kedalaman perairan antara 9-14 $\mathrm{m}$. Hal ini sesuai dengan hasil pengamatan Noviyanti (2015) yang mengemukakan bahwa hiu paus banyak muncul pada kedalaman 5-20 m dengan jarak sekitar $500 \mathrm{~m}$ dari tepi pantai perairan Probolinggo.

Pada umumnya, hiu merupakan spesies karnivora dan cenderung buas ketika memangsa makanannya. Namun hal ini berbeda dengan hiu paus, yang merupakan salah satu dari tiga hiu pemakan plankton lainnya, yaitu hiu bermulut besar (Megachasma pelagios) dan hiu penjemur (Cetorhinus maximus). Clark \& Nelson (1997) menjelaskan bahwa pola pergerakan hiu paus dan area yang biasa menjadi lokasi musimannya dalam periode mingguan/bulanan maupun tahunan menunjukkan adanya keterkaitan dengan peningkatan kelimpahan mangsa secara musiman. Selain itu, Heyman et al., (2001) menjelaskan bahwa hiu paus memiliki kebiasaan makan dengan menyaring air laut untuk mendapatkan zooplankton. Kemunculannya ke permukaan dengan membuka mulut merupakan cara makan surface and subsurface passive feeding, yaitu berenang dan menyaring air di dan di bawah permukaan air. Air yang telah masuk sementara ditutup oleh faring dan kemudian partikel yang bukan makanannya dipilah dengan menggunakan insang hingga kemudian dikeluarkan bersama air. Faring merupakan bagian dari alat pencernaan dan pernafasan hiu paus. Hiu paus makan dengan posisi diam baik secara horisontal maupun vertikal di atau di bawah permukaan air, yang selanjutnya membuka mulutnya untuk menghisap air.

Suhu permukaan laut memiliki peran penting dalam distribusi/sebaran hiu paus. Suhu dapat memicu migrasi suatu spesies yang bisa dilihat sebagai wujud dari perilaku termoregulasi (Binder et al., 2011), proses yang dilakukan oleh organisme dalam mengontrol suhu tubuhnya (Abby, 2015). Rowat (2007) melaporkan bahwa mereka biasanya ditemukan pada suhu $28-32^{\circ} \mathrm{C}$. Selain itu, hiu paus di Ningaloo diketahui lebih menyukai perairan yang hangat dan teramati pada perairan dengan suhu antara $24^{\circ} \mathrm{C}$ sampai $32^{\circ} \mathrm{C}$ (Sleeman et al., 2007). Selain sebagai pemicu migrasi, perilaku termoregulasi lainnya juga dapat terjadi pada hiu paus. Thums et al., (2012) menjelaskan bahwa hubungan antara suhu minimum rata-rata hiu paus saat beraktivitas dan rata-rata turunnya hiu paus menyelam dari permukaan perairan adalah minimum $25^{\circ} \mathrm{C}$.

Integrasi antara data lokasi kemunculan suatu spesies dengan informasi multi sensor penginderaan jauh dalam platform pemodelan dapat menawarkan cara yang kuat dan inovatif (a powerful and innovative 
way) untuk mengidentifikasi daerah potential munculnya suatu spesies dan dapat digunakan untuk mendukung keputusan manajemen perikanan (fisheries management decisions).

\section{KESIMPULAN}

Munculnya hiu paus di suatu wilayah sangat dipengaruhi oleh kondisi oseanografi dan kedalaman perairan tersebut. Munculnya hiu paus di perairan Probolinggo diduga sangat dipengaruhi oleh faktor kedalaman perairan $(9-14 \mathrm{~m})$ disusul oleh ketersedian makanan $\left(0,5-0,9 \mathrm{mg} / \mathrm{m}^{3}\right)$ dan terakhir adalah sea surface temperature $\left(29-30^{\circ} \mathrm{C}\right)$. Bulan Februari merupakan waktu yang paling sering ditemukan kemunculan hiu paus di perairan Probolinggo. Oleh karena itu, untuk menjaga kelestarian hiu paus khususnya di perairan Probolinggo, maka diharapkan nelayan tidak melakukan penangkapan ikan pada kedalaman khususnya $9-14 \mathrm{~m}$ terutama pada saat hiu paus sering muncul yaitu pada bulan Februari.

\section{PERSANTUNAN}

Terima kasih kami sampaikan kepada whalesharkindonesia.org atas dijinkannya menggunakan data kemunculan hiu paus, NASA's Goddard Space Flight Center untuk data SST dan chl-a serta kepada British Oceanographic Data Centre untuk data bathymetri.

\section{DAFTAR PUSTAKA}

Abby. (2015). Thermoregulation. Fishionary. Online.http://fishionary.fisheries.org/tag/thermoregulation/

Anderson, R.C.,\&Ahmed, H. (1993). Shark fisheries of the Maldives. Ministry of Fisheries and Agriculture, Maldives, and FAO, Rome.

Binder, T.R., Cooke, S.J.,\& Hinch, S.G. (2011). The Biology of fish migration. In: Farrell A.P., (ed.). Encyclopedia of Fish Physiology: From Genome to Environment. 3, 1921-1927. San Diego: Academic Press.

Clark, E.,\& Nelson, D.R. (1997). Young whale sharks, Rhincodon typus, feeding on a copepod bloom near La Paz, Mexico. Environmental Biology of Fishes. 50: 63-73. DOI: 10.1023/ A:1007312310127.

Colman, J.G. (1997). AReview of the biology and ecology of the Whale Shark. Journal of Fish Biology. 51, 12191234. DOI: 10.1111/j.1095-8649.1997.tb01138.x
Compagno, L.J.V. (2002). Sharks of the world: An annotated and illustrated catalogue of shark species known to date, Vol. 2. Bullhead, Mackerel and Carpet Sharks (Heterodontiformes, Lamniformes, and Oretolobiformes). FAO Species Catalogue for Fisheries Purposes, No. 1. FAO, Rome.

Clark, E.,\& Nelson, D.R. (1997). Young whale sharks, Rhincodon typus, feeding on a copepod bloom near La Paz, Mexico. Environmental Biology of Fishes. 50, 63-73. DOI: 10.1023/A:1007312310127

de la Parra Venegas, R., Hueter, R., González Cano, J., Tyminski, J.,Remolina, J. G., Maslanka, M., Ormos, A., Weigt, L., Carlson, B.,\&Dove, A.(2011). An unprecedented aggregation of whale sharks, Rhincodon typus, in Mexican coastal waters of the Caribbean Sea. PLoS ONE 6: e18994

Duffy, C.A.J. (2002). Distribution, seasonality, lengths, and feeding behavior of whale sharks (Rhincodon typus) observed in New Zealand waters. Short communication. New Zealand Journal of Marine and Freshwater Research. 36, 565-57.

Eckert, S.A.,\& Stewart, B.S. (2001). Telemetry and satellite tracking of whale sharks, Rhincodon typus, in the Sea of Cortez, Mexico, and the north Pacific Ocean. Environmental Biology of Fishes. 60, 299-308.

Edren, S.M.C., Wisz, M.S., Teilmann, J., Dietz, R.,\& Soderkvist, J. (2010). Modelling spatial patterns in harbour porpoise satellitesatellitetelemetry data using maximum entropy. Ecography, 33, 698-708.

Elith, J., Graham, C.H., Anderson, R.P., Dudik, M. Ferrier, S., Guisan, A., Hijmans, R.J., Huettmann, F., Leathwick, J.R., Lehmann, A., Li, J.,Lohmann, L. G., Loiselle,B. A., Manion,G.,Moritz,C., Nakamura, M., Nakazawa, Y., Overton, J., Peterson,Mc, C, A. T., Phillips, S. J., Richardson, K.,Scachetti-Pereira, R.,Schapire, R. E. J.Soberón,Williams,S.,Wisz, M. S.,\&Zimmermann, N. E. (2006). Novel methods improve prediction of species' distributions from occurrence data. Ecography, 29, 129-151.

Elith, J., Phillips, S.J., Hastie, T., Dudík, M., Chee, Y.E., \&Yates, C.J. (2011). A statistical explanation of MaxEnt for eco logists. Drivers Distrib, 17, 43-57.

Franklin, J. (2009). Mapping species distributions: spatial inference and prediction. Cambridge University Press, Cambridge, UK. 
Guisan, A.,\& Thuiller, W. (2005). Predicting species distribution: offering more than simple habitat models. Ecol Lett, 8, 993"1009.

Hacohen-Domené, Ana, Raúl, O. Martínez-Rincón, Felipe Galván-Magaña, Natalí Cárdenas-Palomo, Rafael de la Parra-Venegas, Beatriz GalvánPastoriza., \&Alistair D. M. Dove. (2015). Habitat suitability and environmental factors affecting whale shark (Rhincodon typus) aggregations in the Mexican Caribbean. Environmental Biology of Fishes. DOI: 10.1007/s10641-015-0413-5.

Heyman, W. D., Graham, R. T., Kjerfve, B.,\&Johannes, R. E. (2001). Whale sharks, Rhincodon typus,aggregate to feed on fish spawn in Belize. Marine Ecology Progress Series. 215, 275-282.

Ketchum, J.T., Galva 'n-Magan a F., \&Klimley, A.P. (2012). Segregation and foraging ecology of whale sharks, Rhincodon typus, in the southwestern Gulf of California. Environ Biol Fishes, 96(6), 779-795. 8.

Last, P.R.,\& Stevens, J.D. (1994). Sharks and rays of Australia. CSIRO, Australia.

Maharani, W.R., Setiyono, H., \& Setyawan, W.B.(2014).Studi distribusi suhu, salintas, dan densitas secara vertikal dan horisontal di perairan pesisir, Probolinggo, Jawa Timur.Jurnal Oseanografi,3, 151-160.

Norman, B. (2002). CITES Identification manual Whale shark (Rhincodon typus Smith 1829). ECOCEAN. Marine Species Section. Environment Australia

Noviyanti, N.S.(2015).Karakteristik habitat hiu paus Rhincodon typus Smith, 1828 (Elasmobranchii : Rhincodontidae) di Pesisir Kabupaten Probolinggo, Jawa Timur [skripsi].Bogor : Institut Pertanian Bogor.

Pearson, R.G., Raxworthy, C.J., Nakamura, M.,\& Peterson, A.T. (2007). Predicting species distributions from small numbers of occurrence records: a test case using cryptic geckos in Madagascar. J. Biogeogr, 34, 102-117.

Peterson, A.T., Papes, M.,\& Eaton, M. (2007). Transferability and model evaluation in ecological niche modeling: a comparison of GARP and Maxent Ecography, 30, 550-560.

Phillips, S. J., Anderson, R.P.,\&Schapire, R.E. (2006). Maximum entropy modeling of species geographic distributions. Ecol. Model. 190, 231-259.
Rowat, D., \&Gore, M.(2007). Regional scale horizontal and local scale vertical movements of whale sharks in the Indian Ocean off Seychelles. Fisheries Research, 84, 32-40. DOI:10.1016/ j.fishres.2006.11.009

Rowat, D. (2007). Occurrence of whale shark (Rhincodon Typus) in the Indian Ocean: Acase for regional conservation. FisheriesResearch. 84: 96101. DOI:10.1016/j.fishres.2006.11.016

Sakuntala, A.P.(2016).Kajian kemunculan (agregasi) hiu paus (Rhincodon typus) berdasarkan faktor lingkungan (SPL, Klorofil-a dan Arus Permukaan) di Perairan Kabupaten Probolinggo, Jawa Timur [skripsi].Malang : Universitas Brawijaya.

Sleeman, J.C., Meekan, M.G., Jenner, C.K.S., Jenner, M.N., Boggs, G.S.,\&Bradshaw, C.J.A. (2007). Biophysical correlates of marine megafauna distributions at Ningaloo Reef, Western Australia. Marine and Freshwater Research, 58, 608-623. DOI: 10.1071/MF06213

Stevens, J.D. (2007). Whale shark (Rhicodon typus) biology and ecology: a preview of the primary literature. Fisheries Research, 84, 4-9.

Suyarso. (2016). Dinamika dan evolusi pantai Probolinggo, Jawa Timur. Oseanologi dan Limnologi di Indonesia, 1(1), 19-27.

Syah, A. F., Saitoh, S.I., Alabia, I. D.,\&Hirawake, T.(2016). Predicting potential fishing zones for Pacific saury (Cololabis saira) with maximum entropy models and remotely sensed data. Fishery Bulletin:330-342.

Taylor, J.G. (1996). Seasonal occurrence, distribution and movements of the whale shark, Rhincodon typus, at Ningaloo Reef, Western Australia. Marine and Freshwater Research. 47, 637-642. DOI: 10.1071/MF9960637.

Taylor, J.G. (2007). Ram filter-feeding and nocturnal feeding of whale sharks (Rhincodon typus) at Ningaloo Reef, Western Australia. Fisheries Research 84: 65-70. DOI:10.1016/ j.fishres.2006.11.014.

Thums, M., Mark, G., Meekan, Stevens, J., Wilson,S., \& Polovina, J.(2012). Evidence for behavioural thermoregulation by the world's largest fish. Journal of the Royal Society Interface. DOI: 10.1098/ rsif.2012.0477. 